\title{
PENGARUH MEDIA SOSIAL TERHADAP PENGETAHUAN TENTANG QUICK RESPONSE CODE INDONESIAN STANDARD (QRIS)
}

\author{
Nurdin Nurdin ${ }^{1 *}$ Difa Restiti², Risky Amalia ${ }^{3}$ \\ ${ }^{12} 2^{\prime 3}$ Jurusan Perbankan Syariah, Fakultas Ekonomi dan Bisnis Islam, Universitas Islam Negeri (UIN) \\ Datokarama Palu, email: nnurdin@iainpalu.a.cid
}

\begin{abstract}
ABSTRAK
Quick Response Code Indonesian Standard atau QRIS telah menjadi sarana baru dalam bertransaksi secara online. Namun edukasi terhadap masyarakat dalam menggunakan QRIS masih sangat minim. Akibatnya masyarakat kebanyakan memperoleh pengetahuan tentang QRIS lebih banyak dari sumber tidak resmi seperti media sosial. Penelitian ini bertujuan untuk mengetahui bagaimana pengaruh media sosial terhadap pengetahuan tentang QRIS yang diperoleh mahasiswa di peguruan timggi. Penelitian ini menggunakan metode survey dengan sampel mahasiswa Fakultas Ekonomi dan Bisnis Islam Universitas Islam Negeri (UIN) Datokarama Palu. Hasil penelitian ini menunjukkan baha media sosial berpengaruh secara signifikan terhadap pemerolehan pengetahuan tentang QRIS. Hal ini dinyatakan berdasarkan hasil uji SPSS 21 dengan nilai Fhitung sebesar $109.066>$ Ftabel 3,95, dan nilai signifikansi (Sig) ,000 < 0,05 dengan nilai dapat disimpulkan bahwa secara simultan variable Media sosial $(X)$ berpengaruh signifikan terhadap Pengetahuan tentang QRIS (Y). Dengan demikian madia sosial telah menjadi sarana yang efektif dalam pemerolehan pengetahuan baru seperti QRIS.
\end{abstract}

INFORMASI

ARTIKEL 


\section{PENDAHULUAN}

Akses ke teknologi merupakan kunci pembuka untuk memasuki era ekonomi berbasis pengetahuan. Begitu pula dengan akses internet masyarakat dapat memperoleh segala informasi yang mereka butuhkan yang dapat menjadi peluang untuk meningkatkan taraf kehidupan mereka.

Era 4.0 pengguna teknologi dapat berbicara, bersosialisasi, berkomunikasi, dan berdagang secara global, pada waktu nyata dan hampir gratis. Berkat teknologi dan Media sosial juga kita mempunyai penyimpanan dan konektivitas yang tidak terbatas.

Pada dasarnya media sosial merupakan perkembangan mutakhir dari teknologi - teknologi web baru berbasis internet, yang memudahkan semua orang dapat berkomunikasi, berpartisipasi, saling berbagi dan membentuk sebuah jaringan secara online sehingga dapat menyebarluaskan konten mereka sendiri. ${ }^{1}$

Tiga miliar orang, sekitar $40 \%$ populasi dunia menggunakan media sosial dan menurut sejumlah laporan kita menghabiskan rata - rata dua jam setiap hari untuk membagikan, menyukai, menulis cuitas dan memperbaharui perangkat ${ }^{2}$

Menurut asosiasi penyelenggara jasa internet Indonesia (APJII) pada

${ }^{1}$ Dyah Listianing Tyas, A.Djoko Budiyanto, Aib Joko Santoso, "Pengaruh Kekuatan Media Sosial Dalam Pengembangan Kesenjangan Digital", Scientific Journal Of $\begin{array}{llll}\text { Informatics } & 2, & \text { No. }\end{array}$ https://www.googlescholar.com (11 September 2020)

2 Jessica Brown, "Apa Saja Bukti Pengruh Media Sosial Dikehidupan Anda, Artikel. $\quad$ www.bbc.com/Indonesia/Vert-Fut42679432.Amp (11 September 2020) tahun 2017, kurang lebih 143 juta masyarakat Indonesia terhubung dengan internet dan sebanyak 95 persen aktivitas yang mereka lakukan adalah membuka media sosial bahkan Indonesia diprediksi akan menjadi negara dengan pengguna media sosial paling aktif dan paling banyak.

Generasi internet memiliki ambisi sukses yang tinggi yang dalam upaya mencapainya seringkali tidak memperhatikan proses. Adanya kecenderungan seperti ini, membuat mereka cenderung menempuh cara cara yang mudah dan mencari cara pintas dalam mendapatkan hasil yang diinginkan. Adanya kecenderungan seperti ini merupakan peluang bagi pemasar untuk memberikan berbagai kemudahan dalam pembelian barang dan jasa. ${ }^{3}$

Selain dengan perkembangan teknologi yang pesat, pola dan sistem pembayaran dalam transaksi ekonomi terus mengalami perubahan. Kemajuan teknologi dalam sistem pembayaran menggeser peranan uang tunai (currency) sebagai alat pembayaran ke dalam bentuk pembayaran non tunai yang lebih efisien dan ekonomis. ${ }^{4}$ Ketika mekanisme pembayaran dituntut untuk selalu mengakomodir setiap kebutuhan masyarakat dalam hal perpindahan dana secara cepat, aman dan efisien, maka inovasi-inovasi teknologi pembayaran semakin bermunculan dengan sangat pesat. ${ }^{5}$

3Tatik Suryani, Perilaku konsumen di era internet", (Yogyakarta: Graha ilmu, 2013), 251.

"Bambang Pramono, dkk, "Dampak Pembayaran Non tunai terhadap Perekonomian dan Kebijakan moneter”. https://bi.go.id (25 september 2020)

${ }^{5}$ Gunawan, S., Malkan, M., \& Jalil, A. (2019). Peranan Kantor Perwakilan Bank Indonesia Provinsi Sulawesi Tengah Dalam 
Dengan dukungan teknologi pengguna maupun penyedia jasa sistem pembayaran non tunai secara terus menerus mencari alternatif pembayaran non tunai yang lebih efisien dan aman. Melihat hal tersebut Bank Indonesia sebagai bank sentral melakukan kebijakan yang semakin memudahkan masyarakat serta mengikuti trend pembayaran digital.

QRIS ini merupakan bagian dari transformasi digital pada sistem pembayaran Indonesia dalam membantu percepatan pengembangan ekonomi dan keuangan digital. QRIS adalah standar QR code pembayaran untuk sistem pembayaran yang dikembangkan oleh Bank Indonesia dan asosiasi sistem pembayaran Indonesia (ASPI). Munculnya QRIS ini memberi kemudahan dalam bertransaksi secara digital.

Bank Indonesia mewajibkan seluruh penyedia layanan pembayaran non tunai menggunakan QRIS sejak tanggal 1 januari 2020. Dalam kondisi pandemi seperti ini, QRIS membantu dalam menekan angka penyebaran karena meminimalisir penggunaan uang yang berpindah - pindah tangan. Meskipun demikian masih banyak masyarakat yang belum mengetahui mengenai apa itu QRIS, cara penggunaan, serta kegunaannya termasuk para mahasiswa selaku milenial yang seharusnya telah melek akan teknologi yang semakin canggih dan perkembangan sistem pembayaran non digital.

Upaya Meningkatkan Penggunaan Uang Logam. Jurnal Ilmu Perbankan dan Keuangan Syariah, 1(1), 57

\section{TINJAUAN PUSTAKA}

2.1 Pengertian Media sosial

Media sosial adalah media yang didesain untuk memudahkan interaksi sosial yang bersifat interaktif atau dua arah. Media sosial berbasis pada teknologi internet yang mengubah pola penyebaran informasi dari yang sebelumnya bersifat satu ke banyak audiens.

Media sosial menurut Kotler dan Keller adalah sarana bagi konsumen yang digunakan untuk berbagi teks, gambar, audio dan informasi video dengan sesama pengguna maupun sebuah perusahaan. Sedangkan Tim pusat humas Kementerian Perdagangan RI menyebutkan bahwa media sosial adalah sebuah media online, dimana para penggunanya (user) melalui aplikasi berbasis internet dapat berbagi, berpartisipasi, dan menciptakan konten berupa blog, wiki, forum, jejaring sosial dan ruang virtual yang didukung oleh teknologi multimedia yang semakin canggih 6 .

Chris Heuer pendiri sosial media club dan innovator media baru yang dimuat dalam buku Engage berpendapat bahwa terdapat $4 \mathrm{C}$ yang digunakan sebagai indicator dalam menggunakan media sosial, diantaranya yaitu: ${ }^{7}$

1) Context: "How we frame our stories". Bagaimana membentuk sebuah

${ }^{6}$ Atika Husaini, Pengaruh Penggunaan Media Sosial Terhadap Keputusan Pembelian Kuota Internet pada Mahasiswa Fakultas Ekonomi dan Bisnis Islam IAIN Palu, (skripsi ekonomi syariah), (Palu,2019)

${ }^{7}$ Elly Amalia Sholikha Sunarti, "Pengaruh Media Sosial Terhadap Minat Berkunjung Followers (Survei Pada Followers Akun Instagram @batuflowergarden.Cobanrais)”, _ (Jurnal Administrasi Bisnis Universitas Brawijaya). https://researchgate.com (02 desember 2020) 
cerita/pesan (informasi) seperti halnya bentuk dari pesan itu sendiri, penggunaan bahasa dan isi dari pesan tersebut.

2) Communication: "The practice of sharing our sharing story as well as listening, responding and growing". Yaitu berbagi cerita atau pesan (informasi) dengan cara mendengar, merespon, dan dengan berbagai cara yang membuat pengguna merasa nyaman dan pesan tersampaikan dengan baik.

3) Collaboration: "Working together to make things better and more efficient and effective". Yaitu bekerja sama antara sebuah akun atau perusahaan dengan penggunanya di media sosial untuk membuat segala hal menjadi baik dan lebih efektif serta efisien. ${ }^{8}$

4) Connection:"The relationships we forge and maintain". Memelihara hubungan yang telah terbina. Melakukan sesuatu yang bersifat berkelanjutan sehingga pengguna merasa lebih dekat dengan sebuah akunFungsi media sosial.

Selain itu, Media sosial juga memiliki beberapa fungsi sebagai berikut :

1) Media sosial adalah media yang didesain untuk memperluas interaksi sosial manusia menggunakan internet dan teknologi web. ${ }^{9}$

2) Media sosial berhasil mentransformasi praktik komunikasi

${ }^{8}$ Nurdin, N. (2021). A Collective Action In Indonesia Local E-Government Implementation Success. International Journal of Scientific $\mathcal{E}$ Technology Research, 10(2), 160-166

9 Nurdin, N., Stockdale, R., \& Scheepers, H. (2013). The Use of Social Media to Gather Qualitative Data: A Case of Government EProcurement Implementation and Use. 24th Australasian Conference on Information Systems (ACIS) searah media siaran dari satu institusi media ke banyak audience ("one to many") menjadi praktik komunikasi dialogis antar banyak audience ("many to many").

3) Media sosial mendukung demokratisasi pengetahuan dan informasi. Mentransformasi manusia dari pengguna isi pesan menjadi pembuat pesan itu sendiri.

Jenis - jenis Media sosial. ${ }^{10}$

1) Aplikasi Media Sosial Berbagi Video (Video Sharing)

Media Berbagi (Media Sharing) Yaitu situs media sosial yang memungkinkan untuk berbagi dengan media berupa video. ${ }^{11}$ TikTok merupakan contoh dari media ini yang sedang digandrungi milenial.

2) Aplikasi Media Sosial Blog \& Mikroblog

Blog dan mikroblog yaitu aplikasi yang dapat membantu penggunanya untuk menulis secara rinci mengenai berita, opini, pengalaman, ataupun kegiatan sehari-hari, baik dalam bentuk teks, gambar, video, ataupun gabungan dari ketiganya. Kedua aplikasi ini mempunyai peran yang sangat penting baik dalam penyampaian informasi maupun pemasaran produk. Melalui kedua aplikasi tersebut, pihak pemberi informasi dapat dengan leluasa mengiring opini masyarakat atau pengguna internet untuk lebih dekat dengan mereka tanpa harus menyampaikan informasi secara tatap muka.

10Ibid, 23

11 Cahyana Kumbul Widada, Mengambil Manfaat Media Sosial Dalam Pengembangan Layanan, (Jurnal Perpustakaan Universitas Muhammadiyah Surakarta), (Surakarta, 2018). https://www.googlescholar.com . (30 Desember 2020) 
3) Aplikasi Media Sosial Berbagi Jaringan Sosial

Situs jejaring sosial sangat berperan dalam hal membangun dan membentuk brand image suatu produk, karena sifatnya yang interaktif sehingga pengguna dapat dengan mudah mengirim dan menerima informasi, bahkan dapat digunakan sebagai media komunikasi dan klarifikasi yang nyaman antara pemilik produk dengan konsumennya. ${ }^{12}$

4) Aplikasi Berbagi Jaringan Profesional

Para pengguna aplikasi berbagi jaringan professional umumnya terdiri atas kalangan akademi, mahasiswa para peneliti, pegawai pemerintah dan pengamat. Dengan kata lain, mereka adalah kalangan kelas menengah Indonesia yang sangat berpengaruh dalam pembentukkan opini masyarakat. Aplikasi jaringan profesional yang cukup populer di Indonesia antara lain LinkedIn, Scribd dan Slideshare

5) Aplikasi Berbagi Foto

Aplikasi jaringan berbagi foto sangat populer bagi masyarakat Indonesia. Penyebaran program pemerintah juga efektif dilakukan lewat aplikasi ini. Tentu saja, materi yang disebarkan juga harus menyesuaikan karakter aplikasi ini. Aplikasi yang cukup populer di Indonesia antara lain Pinterest, Picasa, Flickr, dan Instagram.

Dalam penelitian ini, penulis mengambil aplikasi yang paling banyak digandrungi milenial dan kalangan mahasiswa yaitu Facebook, Instagram,

12 Rusli, R., \& Nurdin, N. (2021). Understanding Indonesia millennia Ulama online knowledge acquisition and use in daily fatwa making habits. Education and Information Technologies. https://doi.org/10.1007/s10639021-10779-7
Twitter, WhatsApp dan Youtube. Beberapa aplikasi tersebut berasal dari jenis media social yang berbeda - beda.

a. Manfaat Media Sosial

Berikut beberapa manfaat dari Media sosial :

1) Sarana belajar, mendengarkan, dan menyampaikan.

Berbagai aplikasi media sosial dapat dimanfaatkan untuk belajar melalui beragam informasi, data dan isu yang termuat di dalamnya. Selain itu, media sosial juga menjadi sarana untuk menyampaikan berbagai informasi kepada orang lain. Konten dalam media sosial berasal dari berbagai belahan dunia dengan beragam latar belakang budaya, sosial, ekonomi, keyakinan, tradisi dan tendensi. ${ }^{13}$

2) Sarana dokumentasi, administrasi dan integrasi.

Beragam aplikasi di media sosial pada dasarnya merupakan gudang dan dokumentasi berbagai konten, dari yang berupa profil, informasi, kejadian, sampai pada hasil - hasil riset kajian.

3) Sarana perencanaan, strategi dan manajemen

Media sosial ditangan pakar manajemen dan marketing dapat menjadi senjata dahsyat untuk melancarkan perencanaan dan strateginya. Misalnya saja untuk melakukan promosi, menggaet pelanggan setia, menghimpun loyalitas customer, menjajaki market, mendidik publik, sampai menghimpun respons masyarakat.

4) Sarana kontrol, evaluasi dan pengukuran

${ }^{13}$ Nurdin, N. (2012). Penggunaan Media Sosial Online dalam Berdakwah: Kemungkinan Adopsi dan Strategi Pemanfaatannya. AlMishbah: Jurnal Ilmu Dakwah dan Komunikasi, 8(1), 177-198. 
Media sosial bermanfaat untuk melakukan kontrol organisasi dan juga mengevaluasi berbagi perencanaan dan strategi yang telah dilakukan. Media sosial juga dapat digunakan sebagai sarana yang ampuh dalam memblok atau memengaruhi pemahaman publik. ${ }^{14}$

\subsection{Pengetahuan tentang QRIS}

\section{a. Definisi Pengetahuan}

Pengetahuan adalah hasil penginderaan manusia (mata, hidung, telinga, dan sebagainya). Dengan sendirinya, pada waktu penginderaan sampai menghasilkan pengetahuan sangat dipengaruhi oleh intensitas perhatian dan persepsi terhadap objek tersebut. ${ }^{15}$

Menurut Bagus, pengetahuan memiliki beberapa pengertian yaitu ${ }^{16}$ :

1) Pengenalan akan sesuatu

2) Perkenalan dengan sesuatu dari pengalaman actual

3) Persepsi yang jelas akan apa saja yang dipandang sebagai fakta kebenaran atau informasi dan/atau yang ada dalam kesadaran yang dibenarkan dengan cara tertentu.

Ada 6 (enam) tingkatan pengetahuan yang dicakup dalam domain kognitif, yaitu ${ }^{17}$ :

\footnotetext{
${ }^{14} \mathrm{Tim}$ pusat Humas Kementerian Perdagangan RI, Panduan Optimalisasi Media Sosial. 37

${ }^{15}$ Malkan, M., Kurniawan, I., Nurdin, N.,
} \& Noval, N. (2021). Pengaruh Pengetahuan Tentang Pasar Modal Syariah Terhadap Minat Investasi Saham di Pasar Modal Syariah Jurnal Ilmu Perbankan dan Keuangan Syariah, 3(1), 57-73.

${ }^{16}$ Kris H. Timothus, Pengantar metodologi penelitian (Yogyakarta: CV. ANDI,2017), 24.https://books.google.co.id. (03 oktober 2020).

${ }^{17}$ Rara Neni Damayanti, ” Pengaruh Pengetahuan, Kepercayaan Dan Kemudahan Terhadap Minat Menggunakan Sms Banking Pada Civitas Akademika Fakultas Ekonomi Dan Bisnis
1) Tahu (Know)

Tahu diartikan sebagai mengingat suatu materi yang telah dipelajari sebelumnya. Termasuk ke dalam pengetahuan tingkat ini adalah mengingat kembali (recall) sesuatu yang spesifik dari keseluruhan bahan yang dipelajari atau rangsangan yang telah diterima. ${ }^{18^{\prime} 19}$

2) Memahami (comprehension)

Memahami diartikan sebagai suatu kemampuan untuk menjelaskan secara benar tentang objek yang diketahui dan dapat menginterpretasikan materi tersebut secara benar. ${ }^{20} 21$

3) Aplikasi (application)

Aplikasi diartikan sebagai kemampuan untuk menggunakan materi yang telah dipelajari pada situasi atau kondisi real (sebenarnya).

4) Analisis (analysis)

Islam Iain Palu” (Skripsi Perbankan Syariah), (Palu,2020)

18 Nurdin, N., \& Yusuf, K. (2020). Knowledge management lifecycle in Islamic bank: the case of syariah banks in Indonesia. International Journal of Knowledge Management Studies, 11(1), 59-80. https://doi.org/10.1504/ijkms.2020.105073

${ }^{19}$ Nurdin, N., Pettalongi, S. S., \& Yusuf, K. (2018, 27-28 Sept. 2018). Knowledge Management Model in Syariah Banking. 2018 5th International Conference on Information Technology, Computer, and Electrical Engineering (ICITACEE),

${ }^{20}$ Marzuki, M., \& Nurdin, N. (2020). The Influence of Halal Product Expectation, Social Environment, and Fiqih Knowledge on Intention to Use Shariah Financial Technology Products. International Journal of Innovation, Creativity and Change, 13(1), 171-193.

${ }^{21}$ Amiruddin, A., Nurdin, N., \& Ali, M. (2021). Islamic Education Teacher Communication Strategy in Increasing Students' Learning Interest. International Journal of Contemporary Islamic Education, 3(1), 41-61. 
Analisis adalah suatu kemampuan untuk menjabarkan materi atau suatu objek ke dalam komponen-komponen, tetapi masih di dalam satu struktur organisasi, dan masih ada kaitannya satu sama lain.

5) Sintesis (synthesis)

Sintesis adalah suatu kemampuan untuk menyusun formulasi baru dari formulasi-formulasi yang ada.

6) Evaluasi (evaluation)

Evaluasi ini berkaitan dengan kemampuan untuk melakukan justifikasi atau penilaian terhadap suatu materi atau objek. Penilaian penilaian ini didasarkan pada suatu kriteria yang ditentukan sendiri, atau menggunakan kriteria-kriteria yang telah ada. ${ }^{22}$

\section{b. Quick Response Code Indonesian Standard (QRIS) \\ Mekanisme pembayaran dituntut} untuk selalu mengikuti kebutuhan masyarakat dalam perpindahan dana yang cepat, aman dan efisien. Maka, inovasi - inovasi teknologi pembayaran semakin bermunculan dengan sangat pesat. Bank Indonesia dituntut selalu memastikan setiap perkembangan sistem pembayaran harus selalu pada koridor ketentuan yang berlaku. ${ }^{23}$

Quick Response Code Indonesian Standard atau biasa disingkat QRIS

22 Kurniati, K., Nurdin, N., \& Nurasmawati, N. (2020). Improving Students' Cognitive and Affective Domains Students through Fostering Teacher Development International Journal of Contemporary Islamic Education, 2(2), 56-70.

${ }^{23}$ Sahrul Gunawan, dkk, "Peranan Kantor Perwakilan Bank Indonesia Provinsi Sulawesi Tengah Dalam Upaya Meningkatkan Penggunaan Uang Logam", (Jurnal Perbankan dan Keuangan Syariah) (2020). https://jurnaljipsya.org/index.php/jipsya/abo ut/contact (03 Oktober 2020) adalah penyatuan berbagai macam QR dari berbagai penyelenggara jasa sistem pembayaran (PJSP) bersama QR Code. QRIS dikembangkan bersama Bank Indonesia agar proses transaksi menggunakan QR lebih mudah, cepat dan terjaga keamanannya. ${ }^{24}$

QRIS hadir dengan tagline UNGGUL (Universal, Gampang, Untung dan Langsung), yang memiliki makna ${ }^{25}$ :

1) Universal

Inklusif, untuk seluruh lapisan masyarakat tanpa terkecuali.

2) Gampang

Transaksi dilakukan dengan mudah dan aman dalam satu genggaman.

3) Untung

Efisien, satu kode QR untuk semua aplikasi pembayaran digital.

4) Langsung

Transaksi cepat dan seketika, mendukung kelancaran sistem pembayaran

Peraturan yang di keluarkan Bank Indonesia untuk mendukung implementasi QRIS adalah menerbitkan ketentuan PADG No. 21/18/PADG/2019 tanggal 16 Agustus 2019 yang antara lain mengatur ruang lingkup penggunaan QR Code untuk pembayaran, implementasi QRIS sebagai standar nasional, laporan dan pengawasan.

Merchant yang memakai QRIS perlu membuka rekening atau akun pada salah satu penyelenggara QRIS yang sudah berizin dari Bank Indonesia. Dengan begitu merchant telah dapat

24 Bank Indonesia, "Quick Response Code Indonesian Standard (QRIS)", situs resmi Bank Indonesia. https://www.bi.go.id/QRIS/Contents/Default. aspx (03 oktober 2020). 25Ibid. 
menerima pembayaran menggunakan QR dari aplikasi manapun. ${ }^{26}$

Aplikasi Gopay, OVO, DANA, LinkAja dan lain sebagainya adalah contoh aplikasi yang dapat memindai kode QRIS sehingga transaksi dapat lebih efisien atau murah, inklusi keuangan di Indonesia juga lebih cepat, UMKM lebih maju dan dapat mendorong pertumbuhan ekonomi. ${ }^{27}$

Adapun manfaat QRIS bagi pedagang, yaitu ${ }^{28}$ :

1) Mengikuti trend pembayaran secara non tunai-digital potensi perluasan penjualan karena alternatif pembayaran selain kas

2) Peningkatan traffic penjualan

3) Penurunan biaya pengelolaan uang tunai/kecil (tidak memerlukan uang kembalian, sebagian uang penjualan langsung tersimpan di bank, bisa dilihat kapan saja, resiko uang hilang/dicuri menurun)

4) Transaksi tercatat otomatis dan bisa dilihat di history transaksi

5) Kemudahan pembayaran tagihan

6) Mengikuti program pemerintah (BI, Kementerian dan Pemda)

7) Penurunan resiko uang palsu

8) Penjualan berpotensi meningkat karena dapat menerima pembayaran berbasis QR

9) Meningkatkan branding

QRIS hadir dengan beberapa bentuk seperti Pos, Lanyard, Acrylic, struk dan EDC. Adapun transaksi QRIS terbagi menjadi dua yaitu :29

1) Transaksi Off-us

User yang membayar dengan aplikasi penyelenggara dimana

${ }^{26} \mathrm{Ibid}$

27"Masih ribet dengan banyak QR

Code?", (Berita), Bicara edisi 78 no. 7 (2019)

28 Ibid.

29 Ibid. pedagang terdaftar sebagai merchant, maka dana akan masuk kea kun pedagang yang sesuai dengan aplikasi yang digunakan (contoh: BCA mobile ke BCA mobile, LinkAja ke LinkAja)

2) Transaksi On-us

User yang membayar dengan aplikasi penyelenggara dimana pedagang tidak terdaftar sebagai merchant, maka dana akan masuk ke salahsatu akun pedagang yang terdaftar. (contoh: Gopay ke LinkAja atau OVO ke DANA)

\section{c. Indikator Pengetahuan tentang QRIS}

Pengetahuan tentang QRIS sangat berguna dimasa yang serba digital terlebih untuk kelancaran sistem pembayaran non tunai di Indonesia. Sebagai generasi penentu bangsa, mahasiswa haruslah mengetahui dan paham apa itu QRIS. Hal ini mendorong Bank Indonesia untuk semakin gencar memperkenalkan dan menginformasikan mengenai QRIS di media sosial.

Menurut Blanchard \& Thacker, Kategori pengetahuan adalah sebagai berikut yang sekaligus juga dijadikan sebagai indikator yaitu ${ }^{30}$ :

1) Informasi yang didapatkan dan diletakkan dalam ingatan (declarative)

2) Bagaimana informasi dikumpulkan dan digunakan ke suatu hal yang sudah diketahui (procedural)

3) Mengerti tentang how, when dan why informasi tersebut berguna dan dapat digunakan (strategic)

4) Transaksi Online dalam pandangan Islam

\footnotetext{
${ }^{30}$ Yati Suhartini, "Pengaruh Pengetahuan, keterampilan dan kemampuan karyawan terhadap Kinerja karyawan (studi pada industri kerajinan kulit di manding, Bantul, Yogyakarta)", 661. https://researchgate.com (02 desember 2020)
} 


\section{METODE PENELITIAN}

Pendekatan yang digunakan dalam penelitian ini adalah pendekatan kuantitatif, karena penelitian ini berfokus untuk mengetahui pengaruh variabel penggunaan media sosial terhadap pemerolehan pengetahuan tentang QRIS dikalangan mahasiswa. Jumlah sampel semuanya yaitu 90 orang yang dipilih secara purposive dengan menggunakan rumus Slovin.

Penelitian ini adalah penelitian lapangan (field research) yaitu penelitian yang dilakukan secara langsung dilapangan. ${ }^{31}$ Data dalam penelitian ini diambil dengan melakukan survei langsung kepada mahasiswa Fakultas Ekonomi dan Bisnis Islam (FEBI).

Adapun teknik pengambilan sampel pada penelitian ini adalah menggunakan purposive sampling, yaitu salah satu teknik pengambilan sampel dengan pertimbangan khusus agar data dari hasil penelitian yang dilakukan menjadi lebih representatif.

Teknik analisis data yang digunakan dalam penelitian ini adalah analisis kuantitatif dengan menggunakan Statistical Package for Social Science (SPSS) 23 for windows sebagai alat ukurnya. ${ }^{32}$

Analisa data dilakukan dengan tahap uji validitas, reabilitas, uji asumsi klasik, dan uji regresi. Untuk

31 Nurdin, N. (2018). Institutional Arrangements in E-Government Implementation and Use: A Case Study From Indonesian Local Government. International Journal of Electronic Government Research (IJEGR), 14(2), 44-63. https://doi.org/10.4018/ijegr.2018040104

32 Yusuf Adam, "Pengaruh Gaya Kepemimpinan Dan Motivasi Kerja Terhadap Kinerja Karyawan Pada Bank Mandiri KCP Palu Imam Bonjol" (Skripsi Jurusan Perbankan Syariah, IAIN Palu, Palu, 2020), 37-38. pembuktian hipotesis penulis menggunakan uji $\mathrm{F}$ dan uji $\mathrm{T}$ dan uji $\mathrm{R}$ Square. Untuk mengetahui apakah variabel independen berpengaruh signifikan terhadap variabel dependen, dilakukan perbandingan antara $F_{\text {hitung }}$ dengan $F_{\text {tabel }}$ pada tingkat kepercayaan 0,05. 33

\section{HASIL DAN PEMBAHASAN 4.1 Deskripsi Kuesioner dan Sampel Penelitian}

Penelitian ini dilakukan pada Mahasiswa Fakultas Ekonomi dan Bisnis Islam Institut Agama Islam Negeri (IAIN) Palu, Jl. Diponegoro No. 23 Palu. Data penelitian menggunakan instrumen kuesioner yang dibagikan kepada Para Mahasiswa Fakultas Ekonomi dan Bisnis Islam yang terdiri dari 2 Jurusan sebagai sampel penelitian yaitu Perbankan syariah dan Ekonomi syariah. Kuesioner disebarkan oleh peneliti kepada sampel yang diteliti dengan perincian sebagai berikut: Tabel 1.

Deskripsi Kuesioner

\begin{tabular}{|c|c|c|c|c|}
\hline $\begin{array}{c}\text { Jumlah } \\
\text { Sampel }\end{array}$ & $\begin{array}{c}\text { Kuesioner } \\
\text { Disebar }\end{array}$ & $\begin{array}{c}\text { Kuesioner } \\
\text { Kembali }\end{array}$ & $\begin{array}{c}\text { Kuesioner } \\
\text { Diolah }\end{array}$ & Presentase \\
\hline 90 & 90 & 90 & 90 & $100 \%$ \\
\hline
\end{tabular}

Dalam tabel 1 dijelaskan bahwa jumlah sampel yang digunakan dalam penelitian ini adalah 90 orang Mahasiswa Fakultas Ekonomi dan Bisnis Islam IAIN Palu. Data responden dalam penelitian ini dijelaskan dalam tabel sebagai berikut:

33 Sudaryono, Metodologi Penelitian. (Depok : RajaGrafindo Persada, 2013), 154. 
Tabel 2.

Data Responden

\begin{tabular}{|c|c|}
\hline Jenis kelamin & Jumlah Responden \\
\hline Laki-Laki & 28 \\
\hline Perempuan & 62 \\
\hline Jumlah & 90 \\
\hline
\end{tabular}

Pada tabel 2 menunjukan bahwa dari 90 orang sampel Mahasiswa Fakultas Ekonomi dan bisnis Islam dalam penelitian ini yang berjenis kelamin Laki-laki berjumlah 28 orang dan Perempuan 62 orang. Sehingga dapat dilihat bahwa sebagian besar sampel berjenis kelamin perempuan.

Tabel 3.

Jurusan responden

\begin{tabular}{|c|c|}
\hline Jurusan & Jumlah \\
\hline $\begin{array}{c}\text { Perbankan } \\
\text { syariah }\end{array}$ & 45 orang \\
\hline Ekonomi syariah & 45 orang \\
\hline Total & 90 \\
\hline
\end{tabular}

Pada tabel diatas jurusan responden terbagai menjadi dua yaitu Perbankan syariah dan Ekonomi syariah. Jumlah responden di jurusan Perbankan syariah berjumlah 64 orang dan Ekonomi syariah 26 orang. Sehingga sampel terbanyak berasal dari jurusan Perbankan syariah.

Tabel 4.

Lama mengakses Media sosial

\begin{tabular}{|c|c|}
\hline Waktı & Jumlah \\
\hline $2-4$ jam / hari & 27 \\
\hline $4-6$ jam / hari & 20 \\
\hline$>6$ jam / hari & 45 \\
\hline
\end{tabular}

Pada tabel diatas terlihat responden lebih cenderung mengakses media sosial dengan durasi lebih dari 6 jam perhari. Kemudian 27 orang memilih 2-4 jam perhari dan 20 orang 46 jam perhari.

Tabel 5.

Media sosial yang sering digunakan

\begin{tabular}{|c|c|}
\hline Media sosial & Jumlah \\
\hline Youtube & 25 \\
\hline Twitter & 3 \\
\hline Facebook & 23 \\
\hline WhatsApp & 77 \\
\hline Instagram & 41 \\
\hline
\end{tabular}

Tabel diatas menunjukkan jumlah media sosial yang paling sering responden gunakan sehari-hari. Responden memilih WhatsApp berjumlah $77 \quad(85.5 \%)$, Instagram 41(45,5\%), Youtube $25 \quad(27,7 \%)$, Facebook 23( 25,5\%) dan Twitter 3 $(3,3 \%)$.

Tabel 6.

Mengetahui QRIS dari Media Sosial

\begin{tabular}{|c|c|}
\hline Media sosial & Jumlah \\
\hline Youtube & 19 \\
\hline Twitter & 0 \\
\hline Facebook & 12 \\
\hline WhatsApp & 52 \\
\hline Instagram & 50 \\
\hline
\end{tabular}

Pada tabel diatas menunjukkan responden banyak yang mengetahui QRIS melalui media sosial WhatsApp kemudian Instagram, Youtube, dan Facebook. Tidak ada responden yang memilih Media sosial Twitter.

\section{Uji Validitas dan Reliabilitas}

Dengan menggunakan instrument yang valid dan reliable dalam pengumpulan data, maka diharapkan hasil penelitian akan 
menjadi valid dan reliable. Instrument yang dinyatakan valid dan reliable adalah instrument yang berarti alat ukur yang digunakan untuk mendapatkan data itu valid. Sedangkan instrument yang reliable berarti bila digunakan untuk mengukur berkali-kali akan menghasilkan data yang sama.

\section{a. Uji Validitas}

Pengujian dilakukan untuk menguji setiap pernyataan yang berada dalam kuesioner, apakah pernyataan valid atau tidak.

Tabel 7.

Hasil uji Validitas $X$

Item-Total Statistics

\begin{tabular}{|l|l|l|l|l|}
\hline \multicolumn{5}{|c|}{ Item-Total Statistics } \\
\hline Items & $\begin{array}{l}\text { Scale Mean } \\
\text { if Item } \\
\text { Deleted }\end{array}$ & $\begin{array}{l}\text { Scale } \\
\text { Variance if } \\
\text { Item } \\
\text { Deleted }\end{array}$ & $\begin{array}{l}\text { Corrected } \\
\text { Item-Total } \\
\text { Correlation }\end{array}$ & $\begin{array}{l}\text { Cronbach's } \\
\text { Alpha if } \\
\text { Item } \\
\text { Deleted }\end{array}$ \\
\hline X1 & 34.21 & 12.753 & .371 & .837 \\
X2 & 34.20 & 11.847 & .627 & .811 \\
X3 & 34.34 & 11.105 & .542 & .822 \\
\hline X4 & 34.36 & 11.715 & .610 & .812 \\
X5 & 34.43 & 12.001 & .512 & .823 \\
X6 & 34.40 & 11.524 & .659 & .807 \\
\hline X7 & 34.38 & 12.328 & .412 & .834 \\
\hline X8 & 34.47 & 11.578 & .639 & .809 \\
\hline X9 & 34.37 & 11.853 & .579 & .816 \\
\hline
\end{tabular}

Tabel 4.

Hasil uji Validitas $Y$ Item-Total Statistics

\begin{tabular}{|l|l|l|l|l|}
\hline Item & $\begin{array}{l}\text { Scale } \\
\text { Mean if } \\
\text { Item } \\
\text { Deleted }\end{array}$ & $\begin{array}{l}\text { Scale } \\
\text { Variance if } \\
\text { Item } \\
\text { Deleted }\end{array}$ & $\begin{array}{l}\text { Correcte } \\
\text { d Item- } \\
\text { Total } \\
\text { Correlati } \\
\text { on }\end{array}$ & $\begin{array}{l}\text { Cronbach' } \\
\text { s Alpha if } \\
\text { Item } \\
\text { Deleted }\end{array}$ \\
\hline Y1 & 29.62 & 12.260 & .587 & .822 \\
Y2 & 29.83 & 11.489 & .612 & .817 \\
\hline Y3 & 29.71 & 11.354 & .567 & .824 \\
Y4 & 29.58 & 11.887 & .667 & .813 \\
\hline Y5 & 30.00 & 11.730 & .409 & .853 \\
\hline$Y 6$ & 29.67 & 11.618 & .680 & .810 \\
\hline Y7 & 29.46 & 12.408 & .603 & .821 \\
\hline Y8 & 29.59 & 12.020 & .592 & .820 \\
\hline
\end{tabular}

Berdasarkan hasil dari tabel 4.7 dan tabel 4.8 terlihat bahwa rhitung pada kolom Corrected Item Total Correlation dinyatakan valid karena $r_{\text {hitung }}>r_{\text {tabel }}$ $(0,2072)$.

\section{a. Uji Reliabilitas}

Pengujian dilakukan untuk menguji kuesioner secara umum apakah kuesioner tersebut reliebel digunakan untuk penelitian yang sama.

Tabel 9.

Uji Reliabilitas X

Reliability Statistics

\begin{tabular}{|c|c|}
\hline $\begin{array}{l}\text { Cronbach's } \\
\text { Alpha }\end{array}$ & N of Items \\
\hline .836 & 9 \\
\hline
\end{tabular}

Tabel 10.

Uji Reliabilitas $Y$

Reliability Statistics

\begin{tabular}{|l|l|}
\hline Cronbach's Alpha & N of Items \\
\hline .841 & 8 \\
\hline
\end{tabular}

Dari tabel 4.9 dan tabel 4.10 dapat diketahui bahwa variabel Cronbach's Alpha (a) lebih dari 0,60 (a > 0,60) yang artinya bahwa variable $X$ dan $Y$ adalah reliebel. Dengan demikian, maka pengolahan data dapat dilanjutkan ke tahap selanjutnya.

\subsection{Deskripsi Variabel Penelitian}

Selanjutnya adalah melakukan tabulasi data untuk melihat tanggapan responden mengenai variable penelitian yaitu Media sosial (Variabel independen) dan Pengetahuan tentang QRIS (Variabel dependen). Kemudian dicari rata-rata dari setiap jawaban, 
untuk memudahkan penelitian rata-rata tersebut, maka digunakan interval.

Rumus yang digunakan menurut Sudjana dalam Rafli sebagai berikut: ${ }^{34}$

Ket :

$$
\mathrm{p}=\frac{\text { Rentang }}{\text { Banyak Kelas }}
$$

$\mathrm{P}$

$$
\text { : Panjang Kelas Interval }
$$

Rentang : Data tertinggi - Data terendah

Banyak kelas : 5

Berdasarkan rumus tersebut, maka panjang kelas interval adalah :

$$
\mathrm{P}=\frac{5-1}{5}
$$

Maka, interval dari kriteria penelitian rata-rata dapat diinterprestasikan sebagai berikut :

Sangat tidak setuju : 1,00-1,79

Tidak setuju $\quad: 1,80-2,59$

Ragu-ragu : :2,60-3,39

Setuju : :3,40-4,19

Sangat setuju $\quad: 4,20-5,00$

\subsection{Uji Asumsi Klasik}

Asumsi klasik dimaksudkan untuk mengetahui apakah koefisien regresi yang didapatkan telah sahih (benar dan dapat diterima) serta menghindari kemungkinan adanya penyelenggaraan asumsi klasik yang merupakan asumsi dasar dalam metode analisis. Dengan demikian dapat diharapkan pengambilan keputusan hasil uji statistic nilai estimasi yang sebenarnya.

Asumsi klasik merupakan asumsi dasar dalam metode analisis

${ }^{34}$ Muh.Rafli Ghani, Pengaruh Kedisiplinan Kerja, Keramahan Dan Pengetahuan Costumer Service Terhadap Kepuasan Nasabah Pada PT. Bank BRI Syariah KCP Wolter Monginsidi (Skripsi IAIN Palu), 61 regresi. Hasil uji asumsi klasik disajikan sebagai berikut:

a. Uji Normalitas

Uji normalitas digunakan untuk mengetahui apakah data yang disajikan untuk dianalisis lebih lanjut berdistribusi normal atau tidak. Model regresi yang baik adalah distribusi data normal atau yang mendekati normal. Adapun cara untuk mendeteksinya dengan melihat tabel berikut

Tabel 11.

One-Sample Kolmogorov-Smirnov Test One-Sample Kolmogorov-Smirnov Test

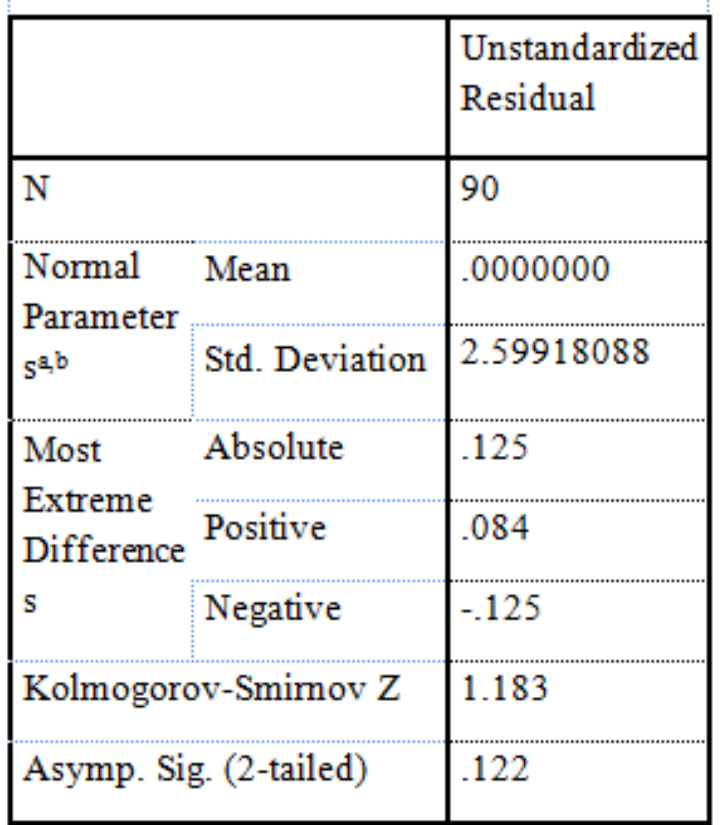

a. Test distribution is Normal.

b. Calculated from data.

Berdasarkan output di atas dapat diketahui bahwa nilai signifikansi Asymp. Sig. (2-tailed) sebesar 0,122. Lebih besar dari 0,05 $(0,122>0,05)$ maka nilai residual tersebut telah normal.

b. Uji heteroskedastisitas

Uji heteroskedastisitas digunakan untuk memenuhi apakah dalam metode regresi telah terjadi ketidaksamaan 
varian dari satu residual pengamatan ke pengamatan yang lain.

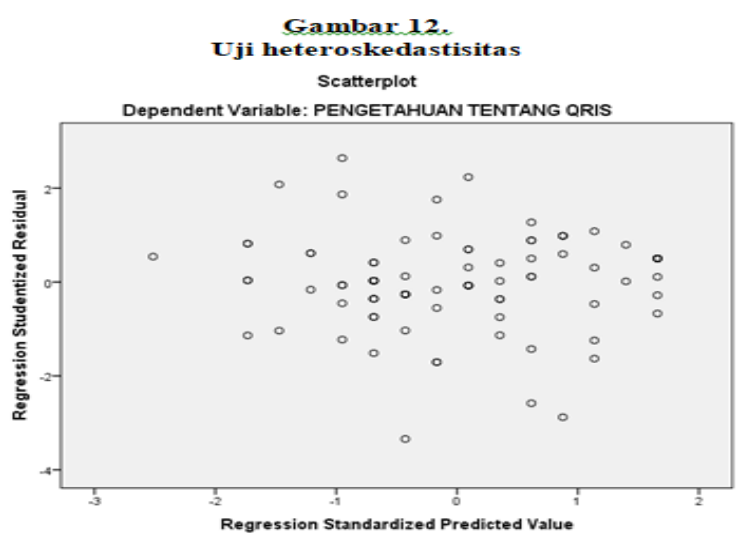

Pada grafik Scatterplot di atas menunjukkan bahwa titik-titik tersebut cenderung menyebar dan tak berpola ataupun berbentuk beraturan, sehingga disimpulkan penelitian ini tidak terjadi heteroskedastisitas.

\subsection{Analisis Regresi Linear Sederhana}

Penelitian ini menggunakan regresi linier sederhana untuk memprediksikan seberapa besar hubungan positif Media sosial terhadap Pengetahuan tentang QRIS. Analisis ini didapatkan dari data kuesioner yang diolah dengan bantuan SPSS v21.

Dari tabel 4.15 menuunjukkan hasil nilai signifikansi yang diperoleh adalah 0,000<0,05. Berdasarkan hasil uji tersebut, dapat disimpulkan bahwa variabel Media sosial (X) berpengaruh terhadap variabel Pengetahuan tentang QRIS (Y).

\section{Uji Parsial (Uji T)}

Uji $t$ dilakukan untuk menunjukan seberapa jauh pengaruh antara variabel bebas dengan terkait. Apabila nilai signifikan (Sig) lebih kecil dari 0,05 maka suatu variabel dinyatakan berpengaruh secara signifikan terhadap variabel yang lain.
Adapun kriteria penerimaan dan penolakan hipotesis adalah:

1) Jika $t$ hitung $>t$ tabel maka Ho ditolak dan Ha diterima

2) Jika $t$ hitung $<t$ tabel maka Ho diterima dan Ha ditolak

Berdasarkan tabel 4.15 maka hasil uji $\mathrm{t}$ pada penelitian ini dapat di jelaskan sebagai berikut :

Tabel 13

\section{Hasil uji T}

Coefficients $^{\mathrm{a}}$

\begin{tabular}{|c|c|c|c|c|c|c|}
\hline \multirow[b]{2}{*}{ Model } & & \multicolumn{2}{|c|}{ Unstandardized Coefficients } & \multirow{2}{*}{$\begin{array}{c}\text { Standardized } \\
\text { Coefficients } \\
\text { Beta } \\
\end{array}$} & \multirow[b]{2}{*}{$t$} & \multirow[b]{2}{*}{ Sig. } \\
\hline & & $B$ & Std. Error & & & \\
\hline \multirow[t]{2}{*}{1} & (Constant) & 1.878 & 1.956 & & .960 & .340 \\
\hline & MEDIA SOSIAL & -.001 & .050 & -.001 & -.013 & .990 \\
\hline
\end{tabular}

Total $X$ keseluruhan sebagai Media sosial memiliki thitung $-0,013<$ $t_{\text {tabel }} 0,677$ dan memiliki nilai signifikan (Sig) 0,990 pada tabel Coefficients dengan nilai a (tingkat signifikan) 0,05. Artinya, $0,990<0,05$ dengan nilai ini memberikan makna bahwa variabel media sosial $X$ tidak memberikan pengaruh secara signifikan terhadap Pengetahuan tentang QRIS (Y).

\section{Koefisien Determinasi}

Analisis koefisien determinasi dilakukan untuk mengetahui seberapa besar pengaruh Media sosial (X) terhadap Pengetahuan tentang QRIS (Y) yang dilakukan dengan menggunakan SPSS 21.

Tabel 14.

Hasil uji Koefisien Determinasi

\begin{tabular}{|c|c|c|c|c|}
\hline \multicolumn{5}{|c|}{ Model Summaryb } \\
\hline Model & $\mathbf{R}$ & $\begin{array}{l}\mathrm{R} \\
\text { Square }\end{array}$ & $\begin{array}{l}\text { Adjusted } \\
\text { R Square }\end{array}$ & $\begin{array}{l}\text { Std. Error of } \\
\text { the Estimate }\end{array}$ \\
\hline 1 & $-744^{a}$ & .553 & .548 & 2.614 \\
\hline
\end{tabular}


Dari hasil tabel diatas menjelaskan bahwa besarnya nilai hubungan (R) yaitu sebesar 0,744 dari output tersebut diperoleh koefisien determinasi ( $R$ Square) 0,553 yang berarti Pengaruh Media sosial $(X)$ terhadap Pengetahuan tentang QRIS adalah sebesar 55,3\%.

\subsection{Pembahasan Hasil Penelitian}

Dari hasil analisis data penelitian, diketahui bahwa Media sosial berpengaruh secara signifikan terhadap Pengetahuan tentang QRIS. Hal ini dinyatakan berdasarkan hasil uji SPSS 21 dengan nilai Fhitung sebesar 109.066 $>$ Ftabel 3,95, dan nilai signifikansi (Sig) $, 000<0,05$ dengan nilai dapat disimpulkan bahwa secara simultan variable Media sosial $(X)$ berpengaruh signifikan terhadap Pengetahuan tentang QRIS (Y).

Dalam memperoleh informasi Media sosial memiliki peran tersendiri apalagi di Era yang serba digital. Media sosial menjadikan penyebaran informasi menjadi cepat dan efisien. Termasuk berbagai produk, kebijakan dan trend baru di Masyarakat termasuk QRIS.

Berdasarkan hasil analisis jawaban responden yaitu Mahasiswa FEBI IAIN Palu, Media sosial memberikan pengaruh sebesar 55,3\% terhadap Pengetahuan tentang QRIS. Yang dimana hal ini didasari atas itensitas penggunaan Media sosial yang cenderung lama dikalangan Mahasiswa dan promosi QRIS yang semakin gencar di Media sosial.

Pembayaran melalui transaksi digital (nirsentuh) harus menjadi pilihan pembayaran yang diutamakan untuk mengurangi risiko penularan. Pembayaran menggunakan QRIS dapat dilakukan tanpa kontak fisik dan mematuhi anjuran Protokol kesehatan yaitu Social Distancing . Selain itu, QRIS juga telah terintegrasi di aplikasi mobile banking / mobile payment .

Dalam demografi kuesioner penelitian diperoleh pula hasil Pengetahuan tentang QRIS banyak didapatkan Mahasiswa dari aplikasi WhatsApp yang umumnya disebarkan oleh para agen QRIS yang berasal dari Mahasiswa penerima beasiswa Bank Indonesia yaitu GenBI SulTeng.

Penyebaran informasi yang disebarkan telah menambah pengetahuan Mahasiswa FEBI terhadap QRIS. Selain itu, aplikasi lain juga memiiki peran dalam memperoleh informasi tentang QRIS bagi Mahasiswa seperti Instagram, Facebook dan juga Youtube.

Pentingnya pengetahuan akan perkembangan teknologi sistem pembayaran khususnya QRIS yang semakin berkembang memberikan manfaat untuk orang banyak. Selain mempercepat transaksi, QRIS juga hadir demi keamanan merchant dan juga pembeli.

Dalam sebuah hadist, disebutkan bahwa salah satu bentuk amalan yang pahalanya tidak terputus bahkan setelah ia wafat adalah ilmu yang bermanfaat.

"Jika seorang manusia mati, maka terputuslah darinya semua amalnya kecuali dari tigal hal; dari sedekah jariyah atau ilmu yang diambil manfaatnya atau anak shalih yang mndoakannya" (HR. Muslim no. 1631) 35

Penelitian ini juga sejalan dengan penelitian yang dilakukan oleh I Wayan Arta Setiawan dari Universitas

${ }^{35}$ Bayumi Nasrul Hoir, " Sains dan Teknologi Perspektif Hadis ", (UIN Sultan Maulana Hasanuddin Banten). https://googlescholar.com (03 Agustus 2021) 
Udayana, Bali mengenai persepsi UMKM tentang QRIS. Dalam penelitiannya faktor-faktor yang mempengaruhi persepsi positif UMKM terhadap QRIS adalah adanya peran influencer yang mempromosikan QRIS di Media sosial ${ }^{36}$.

QRIS sebagai alat pembayaran yang menguntungkan, sebagai alternatif pembayaran, lebih higienis karena dapat mengurangi kontak fisik, mudah digunakan, memudahkan pembayaran, bentuk sederhana, hanya perlu menempatkan QR code di depan meja kasir $^{37}$.

\section{KESIMPULAN}

Hasil penelitian ini menunjukkan baha media sosial berpengaruh secara signifikan terhadap pemerolehan pengetahuan tentang QRIS. Hal ini dinyatakan berdasarkan hasil uji SPSS 21 dengan nilai Fhitung sebesar 109.066 $>$ Ftabel 3,95, dan nilai signifikansi (Sig) ,000 < 0,05 dengan nilai dapat disimpulkan bahwa secara simultan variable Media sosial $(X)$ berpengaruh signifikan terhadap Pengetahuan tentang QRIS $(\mathrm{Y})$.

Implikasi penelitian ini bahwa media sosial dapat menjadi sumber penyebaran pengetahuan baru kepada masyarakat seperti halnya pengetahuan tentang QRIS. Dengan demikian berbagai perusahaan sebaiknya lebih memberdayakan media sosial dalam

36 I Wayan Arta Setiawan dan Luh Putu Mahyuni, "QRIS dimata UMKM: Eksplorasi persepsi dan Intensi UMKM menggunakan QRIS", (Jurnal Ekonomi dan Bisnis Universitas Udayana). https://researchgate.com (02 Maret 2021)

37Ibid. mendidik konsumen mereka tentang berbagai produk yang mereka hasilkan.

\section{DAFTAR PUSTAKA}

Amiruddin, A., Nurdin, N., \& Ali, M. (2021). Islamic Education Teacher Communication Strategy in Increasing Students' Learning Interest. International Journal of Contemporary Islamic Education, 3(1), 41-61.

Atika Husaini, Pengaruh Penggunaan Media Sosial Terhadap Keputusan Pembelian Kuota Internet pada Mahasiswa Fakultas Ekonomi dan Bisnis Islam IAIN Palu, (skripsi ekonomi syariah), (Palu,2019)

Bambang Pramono, dkk, "Dampak Pembayaran Non tunai terhadap Perekonomian dan Kebijakan moneter". https://bi.go.id (25 september 2020)

Bank Indonesia, "Quick Response Code Indonesian Standard (QRIS)", situs resmi Bank Indonesia. https://www.bi.go.id/QRIS/Co ntents/Default.aspx (03 oktober 2020).

Bayumi Nasrul Hoir, " Sains dan

Teknologi Perspektif Hadis ", (UIN Sultan Maulana Hasanuddin Banten).

https://googlescholar.com (03 Agustus 2021)

Cahyana Kumbul Widada, Mengambil Manfaat Media Sosial Dalam Pengembangan Layanan, (Jurnal Perpustakaan Universitas Muhammadiyah Surakarta), (Surakarta, 2018). https://www.googlescholar.com . (30 Desember 2020) 
Dyah Listianing Tyas, A.Djoko Budiyanto, Aib Joko Santoso, "Pengaruh Kekuatan Media Sosial Dalam Pengembangan Kesenjangan Digital", Scientific Journal Of Informatics 2, No. 2. https://www.googlescholar.com (11 September 2020)

Elly Amalia Sholikha Sunarti, "Pengaruh Media Sosial Terhadap Minat Berkunjung Followers (Survei Pada Followers Akun Instagram @batuflowergarden.Cobanrais)", (Jurnal Administrasi Bisnis Universitas Brawijaya). https://researchgate.com Desember 2020)

Gunawan, S., Malkan, M., \& Jalil, A. (2019). Peranan Kantor Perwakilan Bank Indonesia Provinsi Sulawesi Tengah Dalam Upaya Meningkatkan Penggunaan Uang Logam. Jurnal Ilmu Perbankan dan Keuangan Syariah, 1(1), 57-72.

I Wayan Arta Setiawan dan Luh Putu Mahyuni, "QRIS dimata UMKM: Eksplorasi persepsi dan Intensi UMKM menggunakan QRIS", (Jurnal Ekonomi dan Bisnis Universitas Udayana). https://researchgate.com $\quad$ (02 Maret 2021)

Jessica Brown, “Apa Saja Bukti Pengruh Media Sosial Dikehidupan Anda, Artikel.

www.bbc.com/Indonesia/VertFut-42679432.Amp (11 September 2020)

Kris H. Timothus, Pengantar metodologi penelitian (Yogyakarta: CV. ANDI,2017), 24.https:/ / books.google.co.id. (03 oktober 2020).
Kurniati, K., Nurdin, N., \& Nurasmawati, N. (2020). Improving Students' Cognitive and Affective Domains Students through Fostering Teacher Development International Journal of Contemporary Islamic Education, 2(2), 56-70.

Malkan, M., Kurniawan, I., Nurdin, N., \& Noval, N. (2021). Pengaruh Pengetahuan Tentang Pasar Modal Syariah Terhadap Minat Investasi Saham di Pasar Modal Syariah Jurnal Ilmu Perbankan dan Keuangan Syariah, 3(1), 57-73.

Marzuki, M., \& Nurdin, N. (2020). The Influence of Halal Product Expectation, Social Environment, and Fiqih Knowledge on Intention to Use Shariah Financial Technology Products. International Journal of Innovation, Creativity and Change, 13(1), 171193.

Nurdin, N. (2012). Penggunaan Media Sosial Online dalam Berdakwah: Kemungkinan Adopsi dan Strategi Pemanfaatannya. AlMishbah: Jurnal Ilmu Dakwah dan Komunikasi, 8(1), 177-198.

Nurdin, N., Stockdale, R., \& Scheepers, H. (2013). The Use of Social Media to Gather Qualitative Data: A Case of Government EProcurement Implementation and Use. 24th Australasian Conference on Information Systems (ACIS)

Nurdin, N., Pettalongi, S. S., \& Yusuf, K. (2018, 27-28 Sept. 2018). Knowledge Management Model in Syariah Banking. 2018 5th International Conference on Information Technology, 
Computer, and Electrical Engineering (ICITACEE),

Nurdin, N. (2018). Institutional Arrangements in E-Government Implementation and Use: A Case Study From Indonesian Local Government. International Journal of Electronic Government Research (IJEGR), 14(2), 44-63. https:// doi.org/10.4018/ijegr.2018 040104

Nurdin, N., \& Yusuf, K. (2020). Knowledge management lifecycle in Islamic bank: the case of syariah banks in Indonesia. International Journal of Knowledge Management Studies, 11(1), 59-80. https:/ / doi.org/10.1504/ijkms.20 20.105073

Nurdin, N. (2021). A Collective Action In Indonesia Local E-Government Implementation Success. International Journal of Scientific $\mathcal{E}$ Technology Research, 10(2), 160166.

Rara Neni Damayanti, " Pengaruh Pengetahuan, Kepercayaan Dan Kemudahan Terhadap Minat Menggunakan Sms Banking Pada Civitas Akademika Fakultas Ekonomi Dan Bisnis Islam Iain Palu" (Skripsi Perbankan Syariah), (Palu, 2020)

Rusli, R., \& Nurdin, N. (2021). Understanding Indonesia millennia Ulama online knowledge acquisition and use in daily fatwa making habits.
Education and Information

Technologies.

https://doi.org/10.1007/s10639021-10779-7

Sahrul Gunawan, dkk, "Peranan Kantor Perwakilan Bank Indonesia Provinsi Sulawesi Tengah Dalam Upaya Meningkatkan Penggunaan Uang Logam", (Jurnal Perbankan dan Keuangan Syariah)

(2020).

https://jurnaljipsya.org/index.p hp/jipsya/about/contact (03 Oktober 2020).

Sudaryono, Metodologi Penelitian. (Depok : RajaGrafindo Persada, 2013), 154.

Tim pusat Humas Kementerian Perdagangan RI, Panduan Optimalisasi Media Sosial. 37

Tatik Suryani, Perilaku konsumen di era internet", (Yogyakarta: Graha ilmu, 2013), 251

Yati Suhartini, "Pengaruh Pengetahuan, keterampilan dan kemampuan karyawan terhadap Kinerja karyawan (studi pada industri kerajinan kulit di manding, Bantul, Yogyakarta)", 661. https://researchgate.com (02 desember 2020)

Yusuf Adam, "Pengaruh Gaya Kepemimpinan Dan Motivasi Kerja Terhadap Kinerja Karyawan Pada Bank Mandiri KCP Palu Imam Bonjol" (Skripsi Jurusan Perbankan Syariah, IAIN Palu, Palu, 2020), 37-3. 